\title{
Biochemical Engineering Approaches for Increasing Viability and Functionality of Probiotic Bacteria
}

\author{
Huu-Thanh Nguyen ${ }^{1,2, *}$, Dieu-Hien Truong ${ }^{3}$, Sonagnon Kouhoundé ${ }^{2}$, Sokny Ly ${ }^{2}$, \\ Hary Razafindralambo ${ }^{4}$ and Frank Delvigne ${ }^{2, *}$
}

1 Natural Products and Industrial Biochemistry Research Group (NPIB), Faculty of Applied Sciences, Ton Duc Thang University, 19 Nguyen Huu Tho, Tan Phong Ward, District 7, 700000 Ho Chi Minh City, Vietnam

2 Microbial Processes and Interactions (MiPI), Agro-biochem Department, Gembloux Agro-Bio Tech, University of Liège, Passage des Déportés 2, 5030 Gembloux, Belgium; kouhoundes@hotmail.fr (S.K.); soknyly@gmail.com (S.L.)

3 Faculty of Applied Sciences, Ton Duc Thang University, 19 Nguyen Huu Tho, Tan Phong Ward, District 7, 700000 Ho Chi Minh City, Vietnam; truongthidieuhien@tdt.edu.vn

4 Food technology and Formulation, Agro-Biochem Department, Gembloux Agro-Bio Tech, University of Liège, Passage des Déportés 2, 5030 Gembloux, Belgium; hr436028@scarlet.be

* Correspondence: nguyenhuuthanh@tdt.edu.vn (H.-T.N.); f.delvigne@ulg.ac.be (F.D.); Tel.: +32-8162-2306 (H.T.N. \& F.D.); Fax: +32-8161-4222 (H.T.N. \& F.D.)

Academic Editor: Marianne Su-Ling Brooks

Received: 26 March 2016; Accepted: 18 May 2016; Published: 2 June 2016

\begin{abstract}
The literature presents a growing body of evidence demonstrating the positive effect of probiotics on health. Probiotic consumption levels are rising quickly in the world despite the fluctuation of their viability and functionality. Technological methods aiming at improving probiotic characteristics are thus highly wanted. However, microbial metabolic engineering toolbox is not available for this kind of application. On the other hand, basic microbiology teaches us that bacteria are able to exhibit adaptation to external stresses. It is known that adequately applied sub-lethal stress, i.e., controlled in amplitude and frequency at a given stage of the culture, is able to enhance microbial robustness. This property could be potentially used to improve the viability of probiotic bacteria, but some technical challenges still need to be overcome before any industrial implementation. This review paper investigates the different technical tools that can be used in order to define the proper condition for improving viability of probiotic bacteria and their implementation at the industrial scale. Based on the example of Bifidobacterium bifidum, potentialities for simultaneously improving viability, but also functionality of probiotics will be described.
\end{abstract}

Keywords: biochemical engineering; prebiotics; probiotics; exopolysaccharide; sub-lethal stress; survival; cellular robustness

\section{Introduction}

Probiotics are living microorganisms that are able to promote the health of the host due to their metabolic activities and substances they produce when they are living in the host gastrointestinal tract. This has led to the expansion of their application in many sectors. Probiotics are not only used in food processing [1] but also in medical [2,3], agriculture, and aquaculture industries [4]. Therefore, the global demand of probiotics was valued at $\$ 27.9$ billion in 2011, and is estimated to reach $\$ 44.9$ billion in 2018 with $7 \%$ annual growth [5]. The consumption of probiotics is increasing despite the fact that probiotics have shown large fluctuations in quality [6], and more specifically loss of viability during downstream processing operations (such as centrifugation and drying) [7], and the fact that they are particularly sensitive to changes in the environment [8]. Classical metabolic engineering toolbox cannot be used 
in order to improve the phenotypic properties of probiotics, since the use of genetic modification is a limiter for such application [9] One possible alternative is the use of evolutionary engineering. Indeed, it has been previously shown that laboratory evolution in serial batch or continuous culture can potentially lead to improved phenotypes, e.g., with Lactococcus lactis cells exhibiting an accelerated acidification rate [10]. However, even if the analysis of the evolved phenotypes can be sped up by modern high-throughput sequencing tools, this approach is difficult to apply to the adaptation of strains to downstream processing operations [11]. Currently, new approaches based on biochemical engineering can potentially lead to high yield of living cells in large scale production and high survival rate during storage [7]. Most of the studies performed in this area have been primarily focused on improving the robustness and viability of cells during downstream processing operations (i.e., mainly freeze-drying and to a lesser extent spray-drying) [8,12-14]. However, under these conditions, microorganisms are exposed to fast and intensive stresses. On the other hand, upstream conditions present more potentialities for the application of a diversity of stresses on cells exhibiting different physiological behavior [15]. Indeed, during a cultivation operation, the growing microbial population displays a whole range of phenotypic traits depending on the initial cell density, growth conditions, growth rate, growth phase, etc. In this context, two important features have been reported, i.e., cells in stationary phase are more robust than in exponential phase and cells previously exposed to stress in a given range become more resistant to this kind of stress (or a stress involving genes located into the same regulon, i.e., involving the pleiotropic effect of stress response pathways) [16]. However, in order to successfully apply such strategies, a series of important questions have to be addressed:

What Type of Stress to Apply?

- How to adjust the level of stress, i.e., the amplitude, but also the frequency at which the environmental stimulus is applied to the culture?

- How to implement the results at the industrial level?

These questions will be specifically discussed in the next sections of the paper. More generally, this paper will be focused on the description of the non-genetically modified organisms (non-GMOs) strategies used for producing high-quality probiotic bacteria as well as the technologies used for increasing the robustness of cells during fermentation, downstream processing and storage, for improving the functionality of probiotic in the gastrointestinal tract. As an example, the cultivation of Bifidobacterium bifidum will be more thoroughly described, as well as the technological parameters and the resulting physiological features leading to an improved probiotic quality $[8,13]$.

Since these responses will occur at a phenotypic level only, manufacturers will have to implement these sub-lethal stresses upon generation of each probiotic batch. Manufacturers will also have to ensure that costs incurred implementing these stresses are covered by subsequent downstream bacterial survival.

\section{Exploiting Stresses for Improving Microbial Trait: A Non-GMOs, Biochemical Engineering Approach}

\subsection{Mechanistic View of Stress Response of a Microbial Population}

Bacteria, in general, are able to face a diversity of environmental conditions using complex transcriptional networks. Indeed, most of the responses are controlled at the transcriptional level in bacteria due to their defense mechanisms to improve survival in harsh environments. The response of probiotics depends on differential expression of the associated genes, this expression being governed by the nature, the amplitude, and the frequency of the applied stress. Generally, probiotics responds to environmental stresses by activating different regulons, including: (1) implication in energy metabolism operations; (2) transcription and translation associated operations; (3) implication in nucleotide metabolism and amino acid biosynthesis operations; and (4) cell envelope and cell wall-associated operations. These operations produced chaperone proteins that support the folding of misfolded 
proteins, proteases that hydrolyze irreversibly damaged proteins, transport systems to stabilize osmolality, catalases and superoxide dismutase to decompose reactive oxygen species, as well as proton pumps, decarboxylases enzymes, transporter factors to control intracellular $\mathrm{pH}[17,18]$, and exopolysaccharides that protect the cells during drying process [8,13]. Moreover, these proteins are also involved in the increase of the adhesion capacity, in S-layer production, and in fatty acid metabolism of probiotic bacteria [19].

Stress robustness is a desirable trait for the production of starter cultures. In the case of probiotics, this robustness must be accompanied with traits favoring the development of the microbial population in the gut [7]. As stated before, stress resistance is greater during stationary phase or with cells growing at a lower growth rate, and with cells having encountered prior exposure to stress $[15,20]$. However, there are two additional important features to be considered in order to fully understand the mechanisms behind microbial stress response. The first one is that, upon exposure to stress (i.e., when population shifts from an environmental condition A to B), microbial cells belonging to the same population can react differently. This phenomenon has to be attributed to the phenotypic plasticity of microbial cells and stochasticity resulting from the low amount of biochemical species involved in stress response pathways [21]. Phenotypic heterogeneity must be considered when cell robustness is targeted since this mechanism is also implied in stress resistance and fitness in response to environmental challenge. This mechanism where a given population exhibits different subpopulation with different growth and stress resistance characteristics is called bet-hedging [22]. Thus, care has to be taken for the selection of the appropriate phase of the culture where the majority of the cell among the population is in an appropriate phenotypic state.

These two important features can be captured by the use of modern experimental approach such as flow cytometry. Flow cytometry is a single cell technique giving access to cell individuality and that can release, when coupled to appropriate tagging, to a fast determination of cell physiology. Parameters that can be determined by flow cytometry are ranging from global ones, i.e., viability and vitality [23], to more specific ones, i.e., activation of specific genes, co-factor analysis, and accumulation of intracellular metabolites [24]. Additionally, this technique can now be directly coupled to cultivation devices by using appropriate interface, allowing the profiling of microbial physiology at a single cell resolution during the whole culture $[25,26]$. This last feature is particularly interesting for selecting a specific cultivation phase where stresses have to be applied for the induction of microbial robustness [21,27]. The second important feature of microbial response to stress is the multiplicity of pathways that can be potentially implied in the response. Indeed, microbial cells have evolved by optimizing their fitness to fluctuating environments. System biology approaches (or in other words, "omics" based technologies) have thus to be considered for controlling stress response during bioprocesses [28]. Cultivation and analytical technologies related to the monitoring of stress response in process-related conditions will be considered in the next section.

\subsection{Scale-Up/Down: How to Cope with Industrial Constraints?}

The idea by which cultivation conditions can be modulated for increasing the viability and the functionality of probiotics is not new $[7,14]$. However, additional efforts have still to be provided for the identification of specific stimuli that can be efficiently implemented in industrial fermentation. For example, continuous cultures of probiotic strains can be performed in two-compartment reactors $[29,30]$. The first reactor is conducted under normal conditions, whereas the second reactor placed in series is operated under stress conditions. By this way, several stresses can be performed on the same culture. However, this approach does not take into account the diversity of amplitude and frequency that can be experienced by a microbial culture in industrial bioreactors. An alternative strategy relies on the use of another cultivation device, also based on two compartments, but with a continuous recirculation of the cells between the two compartments. Such devices have been previously used as a scale-down system in order to reproduce environmental fluctuations expected in large-scale bioreactors, where the lack of mixing efficiency leads to the appearance of concentration gradients [31]. 
A typical system comprises a stirred bioreactor connected to a plug-flow recirculation loop, this last section being used for generating a specific gradient field (typically, gradient of $\mathrm{pH}$, nutrient, dissolved oxygen or carbon dioxide and temperature are considered). By this way, it is possible to generate a diversity of stress conditions resulting from the superimposition of the flow path followed by a cell through the gradient field [32]. Previous studies have shown that, if this system generally leads to lower biomass yield coefficient, cells obtained at the end of the process exhibit an increased robustness [33,34]. This increase of robustness has to be attributed to the continuous exposure of cells to fluctuating environmental conditions, impairing growth performance but stimulating various stress response pathways [35]. Such two-compartment scale-down reactor have been previously used in order to increase the robustness of Bifidobacterium bifidum by applying various temperature stress [8]. The comparison of fermentation devices that can be used for improving the viability of probiotics shown in Figure 1.

A

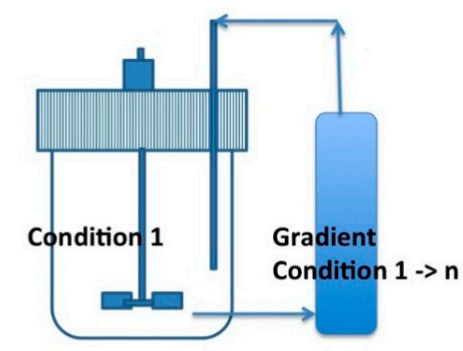

B

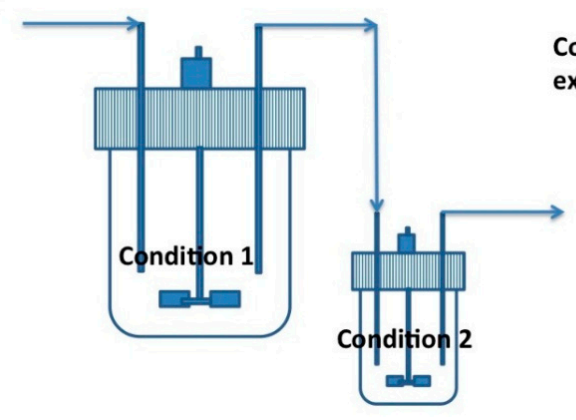

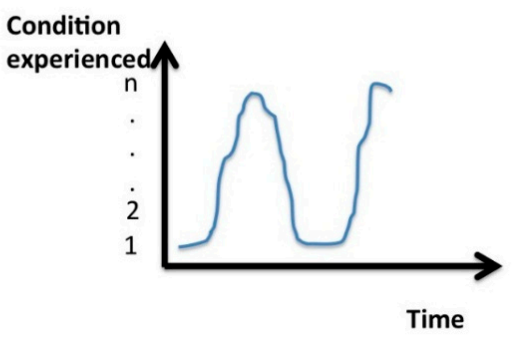

Condition experienced

1

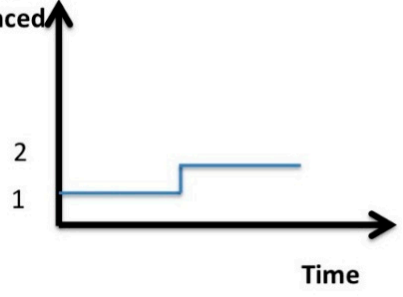

Figure 1. Fermentation devices that can be used for improving the viability of probiotics: (A) Batch cultivation devices based on the recirculation of microbial cells between a stirred bioreactor and a plug-flow recycle loop. By his way, gradient of environmental conditions can be generated at the level of the recycle loop allowing to expose the cells to progressive and recurrent stresses [8]; (B) Continuous cultivation devices based on two stirred bioreactors in series. In this case, only two distinct cultivation conditions can be generated. However, this device had the advantage of maintaining the microbial population at a given stage by chemostat control [7]. Typical single cell traces (i.e., the history of environmental conditions met by cells) are represented for each bioreactor. As shown, the plug-flow recycle loop allows for the generation of much more variable environmental states from 1 to $\mathrm{n}$ (depending on the operating conditions).

All these cultivation devices can be used for the generation of specific environmental conditions leading to improved cell robustness. However, in order to be able to appropriately drive stress resistance during bioprocesses, appropriate monitoring methods are needed. For this purpose, omics-based technologies (i.e., microarray, RNASeq, etc.) can be applied in order to explore the fitness landscape of the strain (i.e., by comparing stress conditions to normal culture conditions) $[10,28]$. On this basis, appropriate biosensors can be used as dynamic parameter for the estimation of stress robustness during cultivation and conditioning. Such biosensor has been developed for the detection of Bacillus species robustness on the basis of the generation of ROS [16]. However, probiotic quality 
does not rely only on robustness, but also to their functionality in the gut. We will show in Section 4 that choosing appropriate upstream conditions can possibly link cell robustness and functionality.

\section{Biotic and Abiotic Factors Yielding to an Increase of Probiotics Quality}

\subsection{Environmental Stresses}

It has been previously documented that environmental stress improved the viability of probiotics after downstream processing [8,36-38]. Sub-lethal treatments drive the physical or chemical stress factors that do not kill cells or organisms but force them to adapt for survival. Many studies suggest that a wide range of environmental stresses were responsible for causing injuries and death to cells [18]. However, the sub-lethal treatment caused by environmental factors (high and low temperature, $\mathrm{pH}$, osmotic, peroxide, bile salt, redox potential, starvation, etc.) allows the bacteria to activate their defense system against intracellular damage, and enhances the viability of probiotics after drying and storage $[17,39]$.

\subsubsection{Exposure to Sub-Lethal Heat Stress}

Excessive environmental temperatures cause protein denaturation, nucleic acid injury, membrane damage [40], and DNA damage in bacteria [41]. However, when bacteria are exposed to harsh temperatures, they reprogram their metabolic systems for responding to changes in their environmental temperature [36].

Sub-lethal temperature stress response has been largely studied in probiotics in recent years [42]. There has been much evidence that the exposure of cells to sub-lethal temperature increases their survival under stressful conditions. The survival rate of Lactobacillus species increased 10-1000-fold, depending on the strain, when exponential phase cells were exposed to a sub-lethal temperature before challenging with a lethal temperature [42]. The improved viability rate of Lactobacillus species that were subjected to sub-lethal temperatures is shown in Table 1.

Table 1. Effect of sub-lethal temperature conditions on survival and heat tolerance to lethal temperature in Lactobacillus $(\mathrm{Lb}$.) strains during the exponential growth phase review by De Angelis [42].

\begin{tabular}{ccccc}
\hline Strain & Lethal Condition & $\begin{array}{c}\text { Surviving } \\
\text { Cells (\%) }\end{array}$ & $\begin{array}{c}\text { Sub-Lethal } \\
\text { Condition }\end{array}$ & $\begin{array}{c}\text { Improved } \\
\text { Viability Rate }\end{array}$ \\
\hline Lb. helveticus LH212 & $63^{\circ} \mathrm{C}, 20 \mathrm{~min}$ & $0.1-1$ & $52^{\circ} \mathrm{C}, 20 \mathrm{~min}$ & 11 \\
Lb. acidophilus NCFM & $63^{\circ} \mathrm{C}, 20 \mathrm{~min}$ & $0.1-1$ & $50{ }^{\circ} \mathrm{C}, 20 \mathrm{~min}$ & 27 \\
Lb. acidophilus LA1-1 & $60^{\circ} \mathrm{C}, 30 \mathrm{~min}$ & 0.003 & $53{ }^{\circ} \mathrm{C}, 30 \mathrm{~min}$ & 166 \\
Lb. casei LC 301 & $54^{\circ} \mathrm{C}, 20 \mathrm{~min}$ & $0.1-1$ & $42^{\circ} \mathrm{C}, 20 \mathrm{~min}$ & 5 \\
Lb. paracasei NFBC338 & $60^{\circ} \mathrm{C}, 10 \mathrm{~min}$ & $\mathrm{ND}$ & $52^{\circ} \mathrm{C}, 15 \mathrm{~min}$ & $300-700$ \\
Lb. collinoides & $52^{\circ} \mathrm{C}, 30 \mathrm{~min}$ & 0.48 & $42^{\circ} \mathrm{C}, 90 \mathrm{~min}$ & 24 \\
\hline
\end{tabular}

The viability rate is calculated as the ratio: survival of adapted cells (\%)/survival of control cells (\%). The controls correspond to non-adapted cells to sub-lethal condition before exposure to lethal condition. ND: Not determined.

The survival rate of Lactobacilli increased significantly compared to the control when cells underwent the sub-lethal temperature before exposure to the lethal temperature [38,43]. Additionally, improved viability rates after exposure to sub-lethal temperature were from 5 to 700 folds higher than the control. These results confirm that the sub-lethal temperature stress improves the heat resistance capacity of Lactobacillus species.

\subsubsection{Exposure to Sub-Lethal Cold}

When the temperature is reduced suddenly, bacteria undergo physiological cell changes, such as changes in membrane fluidity, DNA supercoiling, protein synthesis, and impaired replication of DNA and RNA [42]. To decrease the negative effects of cold temperature, the activity of bacteria must be 
retained at low temperatures, thus leading to a development of transient adaptive cold shock response in probiotic bacteria.

Cold tolerance is one of the most important features of probiotic bacteria, because they must be exposed to cold temperatures during their production, storage and preservation (centrifugation, freezing, freeze-drying, and cold storage). Moreover, probiotic bacteria are also used in the food industry, and these products should be frozen before consumption. Bacteria have to maintain their viability and their probiotic properties at low temperature during the processing and preservation.

Freezing causes cell damage, not only by forming water crystals that injure the cell membrane, but also by changing the osmotic pressure gradient of the nutrients inside and outside of cells [44]. There is well-documented evidence that cells that are subjected to low temperature (e.g., $15^{\circ} \mathrm{C}$ for $2 \mathrm{~h}$ ) before freezing, have an increased survival rate: approximately 10-fold for Lacbacillus sanfranciscensis CB1, 25-fold for Lactobacillus plantarum DB200 and Lactobacillus brevis H12, and 100-fold for Lactobacillus plantarum 20B [45]. The viability of Lactobacillus plantarum L67 increased by $8 \%$ when subjected to cold-stress [46]. According to Fang et al. [47], Streptococcus thermophilus was exposed to cold shock, and its tolerance to a simulated gastric juice and bile solution improved. Cells exposed to low temperature presented higher synthesis of unsaturated and cyclic fatty acids, leading to a higher unsaturated and saturated membranes fatty acid ratio and an increase in the synthesis of four specific proteins leading to cryo-adaptation of probiotics [4].

Besides using the sub-lethal stress, many studies have reported that adaptation stress is also used to improve the survival of probiotic after the drying process, as well as in the production and preservation of cells. The adaptation to low temperature improved the viability of Lactobacillus plantarum by 2-log-units (CFU/mL) [48], and Lactobacillus paracasei NFBC338 by 5-log-units [36,49], respectively.

Therefore, cold shock improved the gastric resistance capacity ( $\mathrm{pH} 2.5$ and 2.8) and the viability of Streptococcus thermophilus after $12 \mathrm{~h}$ of incubation [50].

\subsubsection{Osmotic Stress}

Sodium chloride is often used to induce osmotic stress in probiotics; the effect of this osmotic stress has been reported by many studies. When exposed to the osmotic stress adaptation, probiotic viability was a 0.83-log-unit (CFU/g) higher compared to the unstressed cells [51]. Probiotics adapted to $\mathrm{NaCl}$ stress were significantly more resistant to heat stress of Lactobacillus paracasei NFBC 338 [36,52] and bile [53] than non-adapted control cells. However, the presence of $\mathrm{NaCl}$ enhanced the growth of Lactobacillus plantarum Lp 813 [48]. On the other hand, Lactobacillus rhamnosus HN001 presented significant improvement of their viability in storage at $30^{\circ} \mathrm{C}$ after pre-stressing with $0.6 \mathrm{M} \mathrm{NaCl}$ [37]. Besides this, trehalose is used for improving the heat tolerance but its effect varies, depending on the strain [53].

\subsection{4. $\mathrm{pH}$ and Adaptation}

Adaptation to low $\mathrm{pH}$ allowed the bacteria to improve their resistance to lethal acid conditions [54-56]. When subjected to acid stress conditions, the stress tolerance of the Bifidobacterium longum and Bifidobacterium catenulatum [57] and freeze-drying survival of Oenococcus oeni cells improved [58]. However, the viability of Bifidobacterium longum subsp. longum BBMN68 increased by 70 -fold after exposing cells to $\mathrm{pH} 4.5$ for $2 \mathrm{~h}$ prior to lethal $\mathrm{pH} 3.5$ for $120 \mathrm{~min}$ [59]. Palmfeldt et al. [60] observed the highest survival rate after freeze-drying when the cells were grown at $\mathrm{pH} 5$, and harvested after $2.5 \mathrm{~h}$ compared to those at $\mathrm{pH} 6$ in the stationary phase (review by [42]). However, less is known about the effect of duration of exposure to the stress stimulus and multi-stresses on viability of probiotic bacteria. In fact, very few data have been reported on improving viability by exposing cells to the stress stimulus during fermentation of probiotic bacteria. The two-stage continuous fermentation process was used for the production of stress-adapted probiotics, which increased tolerance to hydrogen peroxide, simulated gastric and intestinal juices, antibiotics and freeze-drying [29]. Moreover, cell immobilization positively affected the resistance of probiotic bacteria in ways such as increases in cell tolerance to 
quaternary ammonium sanitizers, hydrogen peroxide, freeze-drying, gastrointestinal conditions, low $\mathrm{pH}$ and improving their insoluble exopolysaccharide production (review by [7]). Additionally, the heat shock two-compartment bioreactor, which exposed the cells to sub-lethal temperatures, lead to a significant increase in cell recovery after freeze-drying [8]. Although mono-stress is largely studied on diverse probiotic bacteria, multi-stress pre-adaptation has been less investigated. The viability of multi-stress-adapted probiotics was enhanced under gastrointestinal conditions. The mix of multi-stress-adapted probiotics showed effects against foodborne pathogens [61]. Furthermore, as a practical example, combining sub-lethal heat stress and $\mathrm{CO}_{2}$ transfer intensification for optimizing Bifidobacterium bifidum survival rate will be investigated

\subsubsection{Redox Potential}

Probiotics are particularly sensitive to oxygen. There are well-documented studies on their protection against oxygen toxicity during the fermentation process. Strategies to avoid oxygen toxicity include use of special aerobic or oxygen consuming strains [62], use of oxygen scavengers (e.g., ascorbate, L-cysteine, and tea extract) [63,64], microencapsulation [65], adaptation to oxidative stress [66], or use of adequate packaging material [67]. Deoxygenation by inert gases (i.e., nitrogen, carbon dioxide and hydrogen) cause a decrease in redox potential and an improvement survival ability of Bifidobacterium bifidum after drying and while in storage [66,68-70]. It is noted that carbon dioxide can not only maintain the anaerobic growth conditions of Bifidobacterium longum JBL05 but also enhance the cell concentrations and the exopolysaccharide (EPS) secretion [68], and activate the colony formation of Bifidobacterium species [71]

\subsubsection{Carbon Dioxide}

Carbon dioxide has been used for deoxygenizing the culture media before cultivating the probiotic bacteria $[13,69]$. Some evidence demonstrated that the carbon dioxide was able to regulate, not only the physiology, but also the energy metabolism, as demonstrated by upregulation of enzymes involved in glycolysis and homolactic fermentation of streptococcus thermophiles [72]. That led to the improvement of the viability of Bifidobacteria longum and Bifidobacteria [68,71]. However, carbon dioxide can, not only maintain the anaerobic growth conditions of Bifidobacterium longum JBL05, but also enhance the cell concentrations and exopolysaccharide (EPS) secretion [68]. Additionally, there are many reports on the role of phosphoenolpyruvate carboxylase $(\mathrm{PpC})$ and carbamoyl-phosphate synthase on probiotic, which catalyzed the fixation of $\mathrm{CO}_{2}$ to aspartate, arginine, and uracil biosynthesis, respectively [72-77]. In short, the $\mathrm{CO}_{2}$ was used both for creating the anaerobic conditions that improved the probiotic viability and for biosynthesizing amino acids.

\subsection{Co-Cultivation Strategies}

Previous studies have shown that co-culturing different probiotic strains can lead to probiotic mix with improved properties. For example, the viability of probiotic Bacillus species. was improved by co-culturing with Streptococcus thermophilus and Lactobacillus bulgaricus rather than as a mono-culture [78]. Additionally, ruptured Streptococcus thermophilus cells released intracellular components after the early exponential growth phase, which enhanced the growth and function of Lactobacillus casei in co-culture [79]. Moreover, when aerobic and anaerobic facultative microorganisms were used in co-culture, the oxygen uptake metabolism was improved; the content of $\mathrm{O}_{2}$ in the media was decreased, leading to a decrease of oxygen toxicity for probiotic bacteria. The viability of Lactobacillus paracasei $\mathrm{H} 9$ had increased gastrointestinal tolerance due to co-cultured yeast [80]. Similar results were reported on the co-culture of Bifidobacterium bifidum with Lactobacillus species and Streptococcus species, as the probiotic cell concentration remained constant during their storage [81].

However, this strategy is difficult to implement to large-scale conditions, considering the difficulties associated with the synchronization of growth of multiple strains in the same bioreactor. 


\subsection{Other Factors}

Cryo-protectants such as maltodextrin and glycerol were added to probiotic biomass to support cells against adverse environments during drying (review by [82]). Cells were also protected by microencapsulation using alginate calcium before the drying process. Antioxidants, inert gases, and high-oxygen consuming strains were used for reducing the oxygen content of culture or fermentation media [83].

\section{Increasing Functionalities of Probiotics by Exploiting Stress Responses of Probiotic Bacteria}

\subsection{Production of Functional Macromolecules}

Bacteria have developed multiple stress response pathways, organized in network, giving them the potentiality to adapt to environmental stress. The responses to environmental stress of bacteria have been the subject of many studies $[18,41,44,45,84]$. In addition, the main strategies against stress conditions are the synthesis of internal molecules (i.e., functional proteins), the modification of the fatty acid composition of the cell membrane and the alteration of cell surface by inducing synthesis of exopolysaccharides (e.g., EPS forming an extracellular capsule in the case of Bifidobacteria). Indeed, following exposure to environmental stress, many macromolecules can be involved. A proteomics analysis of the biological response of probiotics under stress showed an increase of functional proteins such as GroEL, ClpL1, Hsp family, DnaK, GrpE, DnaJ, ClpS, ATPase family, CspA, NADH oxidase and NADH peroxidase. These are heat and cold shock proteins, or members of the ATP and enzyme family $[49,85,86]$. Moreover, for adaptation to environmental stress, the probiotics can also alter their cell surface by producing extracellular exopolysaccharides, changing their fatty acids composition, and changing surface associated proteins (oligosaccharides building protein) [87-89]. These physiological mechanisms, and more particularly those related to excretion of EPS, can be exploited during upstream operations in order to increase the robustness of the microbial cells (Figure 2).

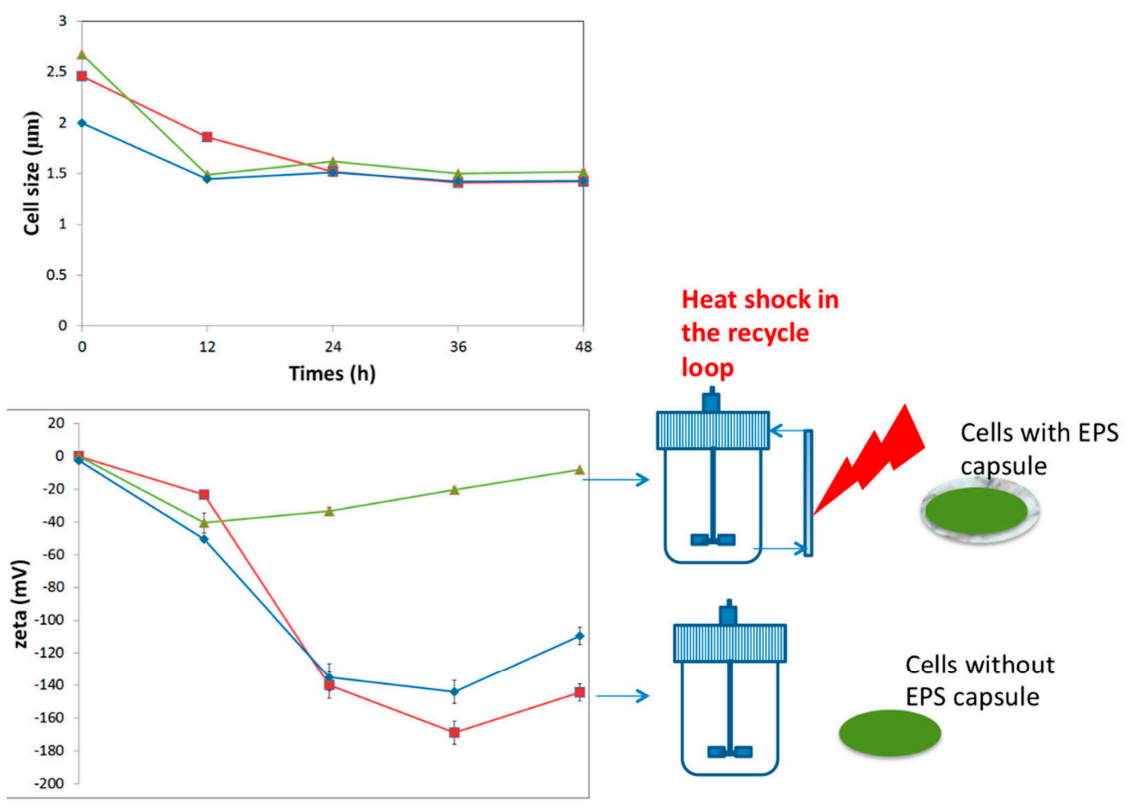

Figure 2. Effect of sub-lethal heat shock $\left(37-42{ }^{\circ} \mathrm{C}\right.$ when cells are crossing the recycle loop, two-compartment reactor, see Figure 1) on cell size and zeta potential. Annulation of zeta potential is observed in the case of the bioreactor performed with heat shock. In this case, stress leads to the excretion of an EPS capsule that can be exploited in order to further increase the robustness of the strain during downstream processing operations (adapted from Nguyen [8]). (square: reference, well-mixed bioreactor, diamond: cold-shock two-compartment bioreactor, triangle: heat-shock two-compartment bioreactor). 


\subsection{Exopolysaccharide Production}

The production of EPS by Lactic acid bacteria and Bifidobacteria has been subjected to large studies $[90,91]$. Most of which reported the effect of medium composition and growth conditions such as carbohydrates, temperature and $\mathrm{pH}$ of growth medium, and stress condition factors [92] to EPS production. In general, there are two types of EPSs; the first type is bound to cell wall (also called attached EPS, or capsular polysaccharides), whereas the other is unattached to cell wall and moves easily in culture (slime EPS, or free EPS) $[93,94]$. Most EPS production by lactic acid bacteria (LAB) are heteropolysaccharide [95]. EPS biosynthesis was a complex biochemical process with the participation of severe extracellular enzymes, which were secreted and localized to the cell wall of bacteria. After synthesis, EPS attaches to the cell wall and carries out its biological functions as a capsule, or is released into the medium as slime $[94,96,97]$.

EPS biosynthesis involves four phases, which are described below.

Phase 1: Transportation of monosaccharides and disaccharides from the environment into the cell

In the cell, sugars are degraded to D-glucose and $\alpha$-D-galactose. Two sugars are broken down by the glycolytic pathway or phosphoketolase pathway [92,96,98]. For EPS biosynthesis, the D-glucose and $\alpha$-D-galactose will be converted into the form of sugar-1 Phosphate [97]

Phase 2: Synthetic sugar-1 Phosphate

Most sugar-6-phosphates are hydrolyzed by the glycolytic pathway for energy and secondary metabolite substances. Under some stress conditions, the sugar-6-phosphates are transformed into sugar-1-phosphates, which are important precursors for the synthesis of EPS repeating units [97].

Phase 3: Synthesis of sugar nucleotides or the EPS repeating uni

The EPS repeating units, such as the UDP-glucose, UDP-galactose, dTDP-rhamnose, UDP-GlcNAc, GDP Fucose, dTDP-Rhamnose, and UDP-Galactofuranose, are synthesized from sugar-1 phosphates. This process is done by a sequence of enzymes encoded by gall $\mathrm{galE}, r f b A, r f b B, r f b C$, and $r f b D$ genes. $[97,99]$. The EPS biosynthesis process of Lactobacillus rhamnosus strains is controlled by a gene cluster distributed on a DNA region of $18.5 \mathrm{~kb}$ encoding the 17 open reading frames (ORFs) and five promoters, of which one is involved in rhamnose biosynthesis [100]. Twenty-one genes (e.g., epsCBAKLDEFGHIJMNOPQRSTU) were predicted to participate in the EPS synthesis process but the participating genes varied for each strain. The size of the EPS specific gene cluster coding for EPS production of Streptococcus thermophilus Sfi 6 was $14.5 \mathrm{~kb}$, it contains 13 genes, and is located on the chromosome, whereas in Lactobacillus lactis NIZO B40, the size is 12 kb, it contains 14 genes, and is located on the plasmid [101]. Contrary to LAB, the reports of genetic analyses of EPS biosynthesis in members of the genus Bifidobacterium are very scarce in literature. The EPS cluster of Bifidobacterium animalis subsp. lactis IPLA-R1 (previously named A1dOxR) was limited to a DNA region of $54.3 \mathrm{~kb}$, including 42 predicted genes flanked by a transposase-encoding gene. The genes in this EPS cluster were similar to those detected in LAB-EPS clusters when compared by homology studies [102]. The EPS cluster of Bifidobacterium breve UCC20003 consists of chromosomal DNA regions of $25.6 \mathrm{~kb}$ with 20 predicted genes, which are located in two adjacent regions (eight genes in the eps 1 operon and 10 genes in the eps 2 operon) [103].

Phase 4: EPS polymerization and export to the surrounding medium

The assembly of the EPS repeating unit in the cell was done by priming-GTF. This enzyme transfers an EPS repeating unit to the lipophilic carrier molecule (C55-polyprenyl phosphate) located in the cytoplasm membrane of cell [104]. This transfer triggers the addition of a repeating unit to the hetero-EPS molecule [92,99]. When an EPS repeating unit is built into the EPS polymer chain, an export process begins to move the finished unit to the extracellular face of the cytoplasmic membrane, 
and to attach it to the cell wall or surrounding medium [51]. The EPS gene cluster contains $14.52 \mathrm{~kb}$ of DNA encoding 13 genes (epsA to epsM) in of Streptococcus thermophilus Sfi6 and $12 \mathrm{~kb}$ of DNA region encoding 14 genes in Lactobacillus lactis subsp. Cremoris NIZO B40 [101]. The structure of the EPS gene cluster showed homology with glycosyl transferases specifically required for the biosynthesis of the EPS-repeating unit at central regions of genes. The homologous enzymes participated in polymerization and export of EPS repeating units (chain-length control, export, and polymerization) that were discovered in two regions flanking the central region, and a region of regulation placed at the beginning of the gene cluster [92]. The biosynthesis of EPS from monosaccharides and disaccharides is summarized in Figure 3.

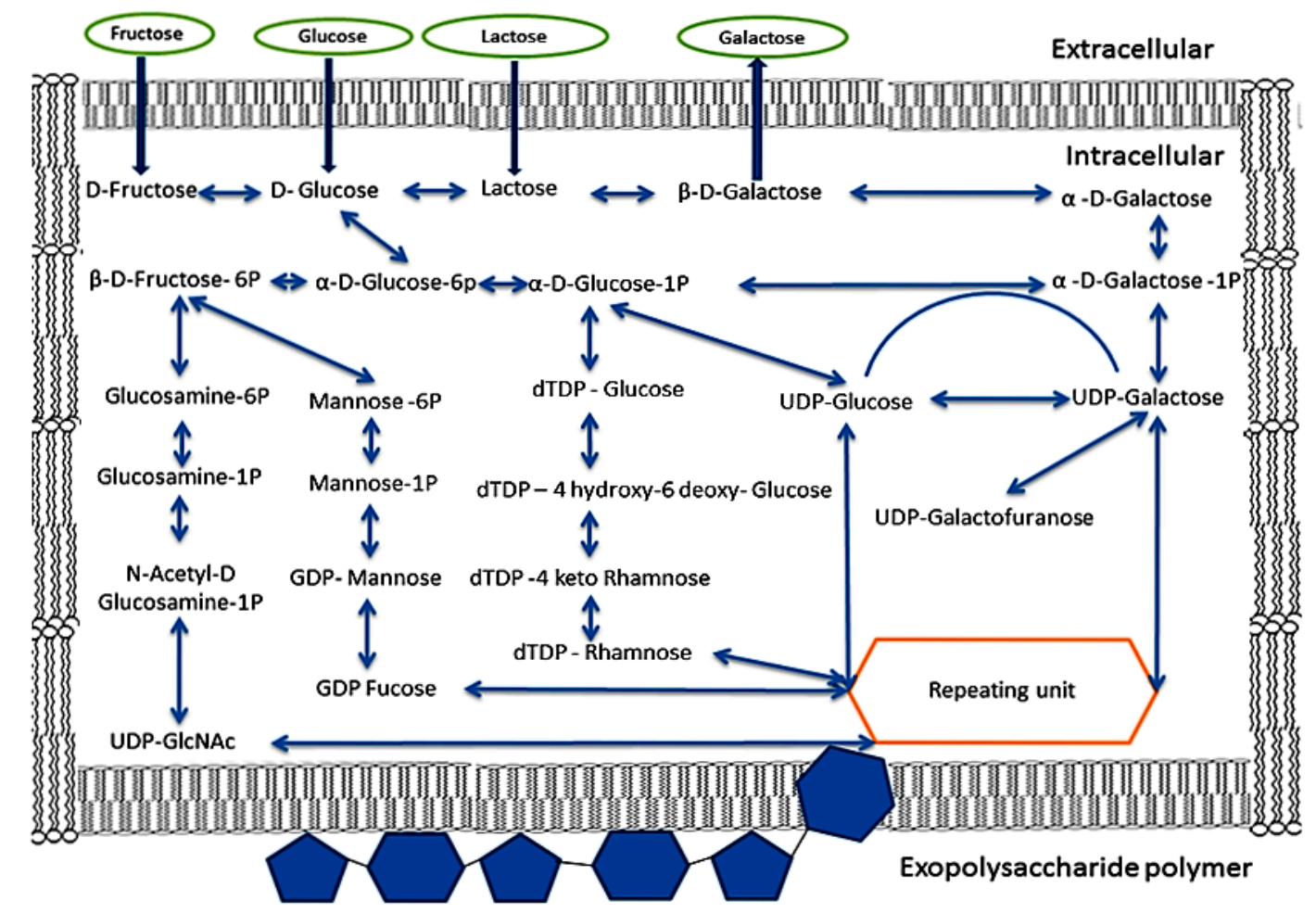

Figure 3. Diagram showing the biosynthetic pathways involved for the production of exopolysaccharides from lactose, fructose, galactose and glucose by lactic acid bacteria.

\subsection{Role of Probiotic Exopolysaccharide}

Exopolysaccharides (EPS) are carbohydrate polymers that are produced by a vast variety of microorganisms as a capsule covering their cell surface. From many years, the application of EPS has been an interesting research topic. EPS is used in diverse sectors, such as food, feed, biotechnology, cosmetics, and medicine. However, the main roles of EPS are described below.

\subsection{Cell Protection Properties}

Some studies indicated that EPS play important roles in bacteria in response to environmental stress, and more specifically, during the drying process [105]. It has been shown that an EPS layer is formed at the cell surface upon water removal. This EPS layer has a protective effect, which is in accordance with the increased viability observed for the microbial cells after drying [106]. One of most important role of EPS is less damage and protecting the cell against the harsh conditions of environment (e.g., protection against desiccation, antibiotics, toxic compounds and osmotic stress [107]). There is strong evidence that the amount of EPS produced is related to the thermoresistance and stimulation of the viability of probiotics during freezing and freeze-drying [91], as well as during storage of 
freeze-dried cells [105,108-115]. The addition of EPS to the food matrix can help probiotics in enhancing the microbial adhesion to the intestinal epithelium and, as a result, the gut colonization is improved by beneficial microorganisms. A steady colonization of the gut is a desirable feature of probiotics [50]. In addition, it is known that EPS excretion leads to an improved robustness of the strains in front of the harsh conditions that can be found in the human gastric system. It also improved the functionality of probiotic strains, e.g., by inhibiting the development of pathogens in the host [111]. Nguyen et al. reported that EPS improved the viability of Bifidobacterium bifidum after freeze-drying [13].

\subsection{Prebiotic Properties}

In previous studies, the EPS produced from the probiotic are heteropolysaccharides that are formed by linking monosaccharides in their structure (e.g., rhamnose, glucose, galactose, etc.) [92]. Indeed, the EPS composition was similar in prebiotics (i.e., the polysaccharide inulin or fructo-oligosaccharides (FOS) derived from various crops or from sucrose) and galacto-oligosaccharides (GOS). Many reports show that the EPS produced from LAB have prebiotic characters such as non-digestibility, fermentable by the intestinal microbiota, and selective stimulation of growth and activity of intestinal bacteria [116,117]. EPS produced by Lactococcus lactis subsp. cremoris are readily degraded through the digestive passage in rat and humans [91], while EPS from Lactobacillus lactis ssp. cremoris B40, Lactobacillus sakei 0-1, Streptococcus thermophilus SFi20, Lactobacillus helveticus Lh59, and Streptococcus thermophilus SFi 39 and SFi 12 are readily degraded by both soil and fecal inocula [118]. Excreted levan-type EPS from Lactobacillus sanfranciscensis showed a bifidogenic effect, although it increased the growth of clostridia [97]. The size of Bifidobacteria population increased significantly in fecal samples when co-fermented with EPS producing strain Pediococcus damnosus in human [119]. There have been many reports that the exopolysaccharides produced by Lactobacillus species have been linked to potential health benefits [90].

\section{Application of Probiotic Functionalities}

\subsection{Food Applications}

Lactic acid bacteria have been used in fermentation of foods such as dairy, fermented vegetables, and fermented meats. Their main roles are food safety and preservation, the improvement of food texture, the production of aroma and flavor for food, the production of functional food and changing the food's nutrition due to their metabolic substances, such as chemical food additives (i.e., nitrite, sulfite, propionic acid, sorbic acid, benzoic acid, bacteriocin, and exopolysaccharide). Those substances are applied in food preservation technology [120]. However, the consumer demand for foods with health benefits is rising quickly and that has led the food industry to develop new products such as functional foods containing probiotic bacteria in dairy products and fermented food [121]. There is a rapidly growing demand for incorporating probiotics into food but there is a significant problem with fluctuating viability of probiotics during processing. Industries need a new probiotic that remains stable during processing, storage, handling, transportation and subsequent use in functional foods [7,122]. In food applications, exopolysaccharides play functional roles such as improving the texture of food, prebiotics, and food additives [106]. The synbiotic, combining strong probiotics with prebiotics, will respond to industrial demand.

\subsection{Pharmaceutical Applications}

The application of biochemical bioengineering for the production of probiotics was not only for improving the viability but also to produce EPS with prebiotic characteristics, when probiotics and prebiotics combine to form the synbiotic $[13,123]$. The term synbiotic is used for describing products that are composed of both probiotics and prebiotics [124]. Synbiotics are used in the functional food industry in ways such as the addition of synbiotics to infant formula. There is well-documented evidence that probiotics and prebiotics protect against colon cancer, aid gut flora by consuming the 
resistant starch, and induce the chemopreventive enzyme glutathione transferase $\pi$ in the colon of the rat. Together, these decrease the load of genotoxic agents and increase production of agents that deactivate toxic components in the gut. Synthesized butyrate can also lower cancer risk in the colon [125]. Meanwhile, probiotics play the important role of correcting abnormalities of colonic flora induced by stress [3]. Probiotics show capacities for antitumor, antiulcer, immunomodulatory, antiviral, and cholesterol lowering activities [92,107]. Furthermore, some strains of Bifidobacteria (i.e., Bifidobacterium breve YIT4014 and 4043, and Bifidobacterium bifidum YIT4007) and their EPS also presented antiulcer activity in rats. Bifidobacterium bifidum BF-1 is capable of gastroprotection, as it reduces acute gastric damage by enhancing the production of gastric mucin in a rat model and alleviating gastric symptoms in humans [126]. EPS production from some probiotic bacteria with these characteristics have been expected to correlate with their capacity to regulate the immune response of the host, eliciting both the innate response and adaptation [116,118,127]. In addition, EPS also improves the adherence of bacteria and colonization of human gut $[103,128]$.

\section{Conclusions}

Exposing cells to appropriate environmental stress potentially lead to an increase of probiotic viability. Additionally, probiotic bacteria respond to environmental stresses by producing specific substances, such as exopolysaccharides and proteins. These substances protect the cells from downstream processing operations. EPS could also play a relevant role in cross talk between the EPS-producing bacteria and the gut environment of the host, promoting by this way health beneficial effects. EPS is applied largely in sectors such as the functional food, dairy, medical, and biomaterial industries, but this review shows extended potentialities for using adapted biochemical engineering approaches for the production of synbiotics (a combination of probiotics and prebiotics) allowing the combination in a cost-effective and industrially implementable way of probiotics robustness and functionality.

Acknowledgments: Huu Thanh Nguyen is the recipient of a PhD scholarship from the Vietnamese government (VN356). Sokny Ly is the recipient of a PhD grant from the ARES-CCD (Belgium).

Author Contributions: Huu-Thanh Nguyen initiated this review in partial fulfillment of his experiential education as a PhD student under the supervision of Frank Delvigne. Huu-Thanh Nguyen, Dieu-Hien Truong, Sonagnon Kouhoundé, Sokny Ly, Hary Razafindralambo and Frank Delvigne contributed to its writing and editing.

Conflicts of Interest: The authors declare no conflict of interest.

\section{Abbreviations}

$\begin{array}{ll}\text { EPS } & \text { exopolysaccharides } \\ \text { DNA } & \text { Deoxyribonucleic acid } \\ \text { RNA } & \text { Ribonucleic acid } \\ \text { NADH } & \text { Nicotinamide adenine dinucleotide } \\ \text { ATP } & \text { Adenosine triphosphate } \\ \text { UDP } & \text { uridine } 5^{\prime} \text {-diphosphate } \\ \text { GDP } & \text { guanosine } 5^{\prime} \text {-diphosphate } \\ \text { TDP } & \text { Thymidine diphosphate } \\ \text { LAB } & \text { Lactic acid bacteria }\end{array}$

\section{References}

1. Roy, D. Technological aspects related to the use of bifidobacteria in dairy products. Lait 2005, 85, 39-56. [CrossRef]

2. Madden, J.A.J.; Hunter, J.O. A review of the role of the gut microflora in irritable bowel syndrome and the effects of probiotics. Br. J. Nutr. 2002, 88, s67-s72. [CrossRef] [PubMed] 
3. Eutamene, H.; Bueno, L. Role of probiotics in correcting abnormalities of colonic flora induced by stress. Gut 2007, 56, 1495-1497. [CrossRef] [PubMed]

4. Balcázar, J.L.; Blas, I.D.; Ruiz-Zarzuela, I.; Cunningham, D.; Vendrell, D.; Múzquiz, J.L. The role of probiotics in aquaculture. Vet. Microbiol. 2006, 114, 173-186.

5. Foligné, B.; Daniel, C.; Pot, B. Probiotics from research to market: The possibilities, risks and challenges. Curr. Opin. Microbiol. 2013, 16, 284-292. [CrossRef] [PubMed]

6. Huys, G.; Botteldoorn, N.; Delvigne, F.; de Vuyst, L.; Heyndrickx, M.; Pot, B.; Dubois, J.J.; Daube, G. Microbial characterization of probiotics-Advisory report of the working group "8651 probiotics" of the belgian Superior Health Council (SHC). Mol. Nutr. Food Res. 2013, 57, 1479-1504. [CrossRef] [PubMed]

7. Lacroix, C.; Yildirim, S. Fermentation technologies for the production of probiotics with high viability and functionality. Curr. Opin. Biotechnol. 2007, 18, 176-183. [CrossRef] [PubMed]

8. Nguyen, H.T.; Razafindralambo, H.; Blecker, C.; N’Yapo, C.; Thonart, P.; Delvigne, F. Stochastic exposure to sub-lethal high temperature enhances exopolysaccharides (EPS) excretion and improves Bifidobacterium bifidum cell survival to freeze-drying. Biochem. Eng. J. 2014, 88, 85-94. [CrossRef]

9. Matijasic, M.; Mestrovic, T.; Peric, M.; Cipcic Paljetak, H.; Panek, M.; Vranesic Bender, D.; Ljubas Kelecic, D.; Krznaric, Z.; Verbanac, D. Modulating composition and metabolic activity of the gut microbiota in IBD patients. Int. J. Mol. Sci. 2016, 17. [CrossRef] [PubMed]

10. Bachmann, H.; Pronk, J.T.; Kleerebezem, M.; Teusink, B. Evolutionary engineering to enhance starter culture performance in food fermentations. Curr. Opin. Biotechnol. 2015, 32, 1-7. [CrossRef] [PubMed]

11. Dragosits, M.; Mattanovich, D. Adaptive laboratory evolution-Principles and applications for biotechnology. Microb. Cell Fact. 2013, 12, 64. [CrossRef] [PubMed]

12. Volkert, M.; Ananta, E.; Luscher, C.; Knorr, D. Effect of air freezing, spray freezing, and pressure shift freezing on membrane integrity and viability of Lactobacillus rhamnosus gg. J. Food Eng. 2008, 87, 532-540. [CrossRef]

13. Nguyen, H.; Razafindralambo, H.; Richel, A.; Jacquet, N.; Evrard, P.; Antoine, P.; Thonart, P.; Delvigne, F. Scalable temperature induced stress for the large-scale production of functionalized bifidobacteria. J. Ind. Microbiol. Biotechnol. 2015, 42, 1225-1231. [CrossRef] [PubMed]

14. Mozzetti, V.; Grattepanche, F.; Berger, B.; Rezzonico, E.; Arigoni, F.; Lacroix, C. Fast screening of bifidobacterium longum sublethal stress conditions in a novel two-stage continuous culture strategy. Benef. Microb. 2013, 4, 167-178. [CrossRef] [PubMed]

15. Ryall, B.; Eydallin, G.; Ferenci, T. Culture history and population heterogeneity as determinants of bacterial adaptation: The adaptomics of a single environmental transition. Microbiol. Mol. Biol. Rev. 2012, 76, 597-625. [CrossRef] [PubMed]

16. Abee, T.; Wels, M.; de Been, M.; den Besten, H. From transcriptional landscapes to the identification of biomarkers for robustness. Microb. Cell Fact. 2011, 10, S9. [CrossRef] [PubMed]

17. Mills, S.; Stanton, C.; Fitzgerald, G.F.; Ross, R.P. Enhancing the stress responses of probiotics for a lifestyle from gut to product and back again. Microb. Cell Fact. 2011, 10, S19. [PubMed]

18. Corcoran, B.M.; Stanton, C.; Fitzgerald, G.; Ross, R.P. Life under stress: The probiotic stress response and how it may be manipulated. Curr. Pharm. Des. 2008, 14, 1382-1399. [CrossRef] [PubMed]

19. Ruiz, L.; Margolles, A.; Sanchez, B. Bile resistance mechanisms in lactobacillus and bifidobacterium. Front. Microbiol. 2013, 4, 396. [CrossRef] [PubMed]

20. Booth, I.R. Stress and the single cell: Intrapopulation diversity is a mechanism to ensure survival upon exposure to stress. Int. J. Food Microbiol. 2002, 78, 19-30. [CrossRef]

21. Delvigne, F.; Zune, Q.; Lara, A.R.; Al-Soud, W.; Sorensen, S.J. Metabolic variability in bioprocessing: Implications of microbial phenotypic heterogeneity. Trends Biotechnol. 2014, 32, 608-616. [CrossRef] [PubMed]

22. Martins, B.M.; Locke, J.C. Microbial individuality: How single-cell heterogeneity enables population level strategies. Curr. Opin. Microbiol. 2015, 24, 104-112. [CrossRef] [PubMed]

23. Davey, H.M. Life, death, and in-between: Meanings and methods in microbiology. Appl. Environ. Microbiol. 2011, 77, 5571-5576. [CrossRef] [PubMed]

24. Bridier, A.; Hammes, F.; Canette, A.; Bouchez, T.; Briandet, R. Fluorescence-based tools for single-cell approaches in food microbiology. Int. J. Food Microbiol. 2015, 213, 2-16. [CrossRef] [PubMed]

25. Brognaux, A.; Han, S.; Sorensen, S.J.; Lebeau, F.; Thonart, P.; Delvigne, F. A low-cost, multiplexable, automated flow cytometry procedure for the characterization of microbial stress dynamics in bioreactors. Microb. Cell Fact. 2013, 12, 100. [CrossRef] [PubMed] 
26. Delvigne, F.; Baert, J.; Gofflot, S.; Lejeune, A.; Telek, S.; Johanson, T.; Lantz, A.E. Dynamic single-cell analysis of saccharomyces cerevisiae under process perturbation: Comparison of different methods for monitoring the intensity of population heterogeneity. J. Chem. Technol. Biotechnol. 2015, 90, 314-323. [CrossRef]

27. Delvigne, F.; Goffin, P. Microbial heterogeneity affects bioprocess robustness: Dynamic single-cell analysis contributes to understanding of microbial populations. Biotechnol. J. 2014, 9, 61-72. [CrossRef] [PubMed]

28. Teusink, B.; Bachmann, H.; Molenaar, D. Systems biology of lactic acid bacteria: A critical review. Microb. Cell Fact. 2011, 10, S11. [CrossRef] [PubMed]

29. Doleyres, Y.; Fliss, I.; Lacroix, C. Increased stress tolerance of bifidobacterium longum and Lactococcus lactis produced during continuous mixed-strain immobilized-cell fermentation. J. Appl. Microbiol. 2004, 97, 527-539. [CrossRef] [PubMed]

30. Doleyres, Y.; Lacroix, C. Technologies with free and immobilised cells for probiotic bifidobacteria production and protection. Int. Dairy J. 2005, 15, 973-988. [CrossRef]

31. Delvigne, F.; Destain, J.; Thonart, P. A methodology for the design of scale-down bioreactors by the use of mixing and circulation stochastic models. Biochem. Eng. J. 2006, 28, 256-268. [CrossRef]

32. Delvigne, F.; brognaux, A.; Gorret, N.; Neubauer, P.; Delafosse, A.; Collignon, M.-L.; Toye, D.; Crine, M.; Boxus, M.; Thonart, P. Characterization of the response of GFP microbial biosensors sensitive to substrate limitation in scale-down bioreactors. Biochem. Eng. J. 2011, 55, 131-139. [CrossRef]

33. Delvigne, F.; Brognaux, A.; Francis, F.; Twizere, J.C.; Gorret, N.; Sorensen, S.J.; Thonart, P. Green fluorescent protein (GFP) leakage from microbial biosensors provides useful information for the evaluation of the scale-down effect. Biotechnol. J. 2011, 6, 968-978. [CrossRef] [PubMed]

34. Neubauer, P.; Junne, S. Scale-down simulators for metabolic analysis of large-scale bioprocesses. Curr. Opin. Biotechnol. 2010, 21, 114-121. [CrossRef] [PubMed]

35. Schweder, T. Bioprocess monitoring by marker gene analysis. Biotechnol. J. 2011, 6, 926-933. [CrossRef] [PubMed]

36. Desmond, C.; Stanton, C.; Fitzgerald, G.F.; Collins, K.; Paul Ross, R. Environmental adaptation of probiotic lactobacilli towards improvement of performance during spray drying. Int. Dairy J. 2001, 11, 801-808. [CrossRef]

37. Prasad, J.; McJarrow, P.; Gopal, P. Heat and osmotic stress responses of probiotic Lactobacillus rhamnosus HN001 (DR20) in relation to viability after drying. Appl. Environ. Microbiol. 2003, 69, 917-925. [CrossRef] [PubMed]

38. Saarela, M.; Rantala, M.; Hallamaa, K.; Nohynek, L.; Virkajarvi, I.; Matto, J. Stationary-phase acid and heat treatments for improvement of the viability of Probiotic lactobacilli and bifidobacteria. J. Appl. Microbiol. 2004, 96, 1205-1214. [CrossRef] [PubMed]

39. Serrazanetti, D.I.; Guerzoni, M.E.; Corsetti, A.; Vogel, R. Metabolic impact and potential exploitation of the stress reactions in lactobacilli. Food Microbiol. 2009, 26, 700-711. [CrossRef] [PubMed]

40. Ananta, E.; Volkert, M.; Knorr, D. Cellular injuries and storage stability of spray-dried Lactobacillus rhamnosus gg. Int. Dairy J. 2005, 15, 399-409. [CrossRef]

41. Abee, T.; Wouters, J.A. Microbial stress response in minimal processing. Int. J. Food Microbiol. 1999, 50, 65-91. [CrossRef]

42. De Angelis, M.; Gobbetti, M. Environmental stress responses in lactobacillus: A review. Proteomics 2004, 4, 106-122. [CrossRef] [PubMed]

43. Kim, W.S.; Perl, L.; Park, J.H.; Tandianus, J.E.; Dunn, N.W. Assessment of stress response of the probiotic Lactobacillus acidophilus. Curr. Microbiol. 2001, 43, 346-350. [CrossRef] [PubMed]

44. Thieringer, H.A.; Jones, P.G.; Inouye, M. Cold shock and adaptation. BioEssays 1998, 20, 49-57. [CrossRef]

45. De Angelis, M.; di Cagno, R.; Huet, C.; Crecchio, C.; Fox, P.F.; Gobbetti, M. Heat shock response in Lactobacillus plantarum. Appl. Environ. Microbiol. 2004, 70, 1336-1346. [CrossRef] [PubMed]

46. Song, S.; Bae, D.-W.; Lim, K.; Griffiths, M.W.; Oh, S. Cold stress improves the ability of Lactobacillus plantarum L67 to survive freezing. Int. J. Food Microbiol. 2014, 191, 135-143. [CrossRef] [PubMed]

47. Fang, S.H.; Lai, Y.J.; Chou, C.C. The susceptibility of Streptococcus thermophilus 14085 to organic acid, simulated gastric juice, bile salt and disinfectant as influenced by cold shock treatment. Food Microbiol. 2013, 33, 55-60. [CrossRef] [PubMed]

48. Lourens-Hattingh, A.; Viljoen, B.C. Yogurt as probiotic carrier food. Int. Dairy J. 2001, 11, 1-17. [CrossRef] 
49. Desmond, C.; Fitzgerald, G.F.; Stanton, C.; Ross, R.P. Improved stress tolerance of groesl-overproducing Lactococcus lactis and probiotic Lactobacillus paracasei NFBC 338. Appl. Environ. Microbiol. 2004, 70, 5929-5936. [CrossRef] [PubMed]

50. Russo, P.; Iturria, I.; Mohedano, M.L.; Caggianiello, G.; Rainieri, S.; Fiocco, D.; Angel Pardo, M.; Lopez, P.; Spano, G. Zebrafish gut colonization by mcherry-labelled lactic acid bacteria. Appl. Microbiol. Biotechnol. 2015, 99, 3479-3490. [CrossRef] [PubMed]

51. Hidalgo-Cantabrana, C.; Sanchez, B.; Milani, C.; Ventura, M.; Margolles, A.; Ruas-Madiedo, P. Genomic overview and biological functions of exopolysaccharide biosynthesis in bifidobacterium spp. Appl. Environ. Microbiol. 2014, 80, 9-18. [CrossRef] [PubMed]

52. Desmond, C.; Ross, R.P.; O'Callaghan, E.; Fitzgerald, G.; Stanton, C. Improved survival of Lactobacillus paracasei NFBC 338 in spray-dried powders containing gum acacia. J. Appl. Microbiol. 2002, 93, 1003-1011. [CrossRef] [PubMed]

53. Gouesbet, G.; Jan, G.; Boyaval, P. Lactobacillus delbrueckii ssp. Bulgaricus thermotolerance. Lait 2001, 81, 301-309. [CrossRef]

54. Phadtare, S.; Alsina, J.; Inouye, M. Cold-shock response and cold-shock proteins. Curr. Opin. Microbiol. 1999, 2, 175-180. [CrossRef]

55. Šeme, H.; Gjuračić, K.; Kos, B.; Fujs, Š.; Štempelj, M.; Petković, H.; Šušković, J.; Bogovič Matijašić, B.; Kosec, G. Acid resistance and response to $\mathrm{pH}$-induced stress in two Lactobacillus plantarum strains with probiotic potential. Benef. Microb. 2014, 6, 369-379. [CrossRef] [PubMed]

56. Sánchez, B.; Champomier-Vergès, M.-C.; Collado, M.D.C.; Anglade, P.; Baraige, F.; Sanz, Y.; de los Reyes-Gavilán, C.G.; Margolles, A.; Zagorec, M. Low-pH adaptation and the acid tolerance response of bifidobacterium longum biotype longum. Appl. Environ. Microbiol. 2007, 73, 6450-6459. [CrossRef] [PubMed]

57. Collado, M.C.; Sanz, Y. Induction of acid resistance in bifidobacterium: A mechanism for improving desirable traits of potentially probiotic strains. J. Appl. Microbiol. 2007, 103, 1147-1157. [CrossRef] [PubMed]

58. He, T.; Priebe, M.G.; Zhong, Y.; Huang, C.; Harmsen, H.J.M.; Raangs, G.C.; Antoine, J.M.; Welling, G.W.; Vonk, R.J. Effects of yogurt and bifidobacteria supplementation on the colonic microbiota in lactose-intolerant subjects. J. Appl. Microbiol. 2008, 104, 595-604. [CrossRef] [PubMed]

59. Jin, J.; Zhang, B.; Guo, H.; Cui, J.; Jiang, L.; Song, S.; Sun, M.; Ren, F. Mechanism analysis of acid tolerance response of Bifidobacterium longum subsp. Longum BBMN 68 by gene expression profile using RNA-sequencing. PLoS ONE 2012, 7, e50777.

60. Palmfeldt, J.; Hahn-Hägerdal, B. Influence of culture ph on survival of Lactobacillus reuteri subjected to freeze-drying. Int. J. Food Microbiol. 2000, 55, 235-238. [CrossRef]

61. Mathipa, M.; Thantsha, M. Cocktails of probiotics pre-adapted to multiple stress factors are more robust under simulated gastrointestinal conditions than their parental counterparts and exhibit enhanced antagonistic capabilities against Escherichia coli and Staphylococcus aureus. Gut Pathog. 2015, 7, 5. [CrossRef] [PubMed]

62. Lourens-Hattingh, A.; Viljoen, B.C. Growth and survival of a probiotic yeast in dairy products. Food Res. Int. 2001, 34, 791-796. [CrossRef]

63. Gaudreau, H.; Champagne, C.P.; Remondetto, G.E.; Alvarez, P.A.; Gomaa, A.; Subirade, M. Tea extract render probiotic Lactobacillus helveticus more resistant to oxygen exposure through lipid modification mechanism. Food Res. Int. 2016, 81, 141-148. [CrossRef]

64. Gaudreau, H.; Champagne, C.P.; Remondetto, G.E.; Bazinet, L.; Subirade, M. Effect of catechins on the growth of oxygen-sensitive probiotic bacteria. Food Res. Int. 2013, 53, 751-757. [CrossRef]

65. Kailasapathy, K. Microencapsulation of probiotic bacteria technology and potential applications. Curr. Issues Intest. Microbiol. 2002, 3, 39-48. [PubMed]

66. Rallu, F.; Gruss, A.; Ehrlich, S.D.; Maguin, E. Acid- and multistress-resistant mutants of Lactococcus lactis : Identification of intracellular stress signals. Mol. Microbiol. 2000, 35, 517-528. [CrossRef] [PubMed]

67. Bergmaier, D.; Champagne, C.P.; Lacroix, C. Growth and exopolysaccharide production during free and immobilized cell chemostat culture of Lactobacillus rhamnosus rw-9595m. J. Appl. Microbiol. 2005, 98, 272-284. [CrossRef] [PubMed] 
68. Ninomiya, K.; Matsuda, K.; Kawahata, T.; Kanaya, T.; Kohno, M.; Katakura, Y.; Asada, M.; Shioya, S. Effect of $\mathrm{CO}_{2}$ concentration on the growth and exopolysaccharide production of Bifidobacterium longum cultivated under anaerobic conditions. J. Biosci. Bioeng. 2009, 107, 535-537. [CrossRef] [PubMed]

69. Ebel, B.; Martin, F.; Le, L.D.; Gervais, P.; Cachon, R. Use of gases to improve survival of Bifidobacterium bifidum by modifying redox potential in fermented milk. J. Dairy Sci. 2011, 94, 2185-2191. [CrossRef] [PubMed]

70. Bolduc, M.-P.; Raymond, Y.; Fustier, P.; Champagne, C.P.; Vuillemard, J.-C. Sensitivity of bifidobacteria to oxygen and redox potential in non-fermented pasteurized milk. Int. Dairy J. 2006, 16, 1038-1048. [CrossRef]

71. Kawasaki, S.; Nagasaku, M.; Mimura, T.; Katashima, H.; Ijyuin, S.; Satoh, T.; Niimura, Y. Effect of $\mathrm{CO}_{2}$ on colony development by bifidobacterium species. Appl. Environ. Microbiol. 2007, 73, 7796-7798. [CrossRef] [PubMed]

72. Arioli, S.; Roncada, P.; Salzano, A.M.; Deriu, F.; Corona, S.; Guglielmetti, S.; Bonizzi, L.; Scaloni, A.; Mora, D. The relevance of carbon dioxide metabolism in Streptococcus thermophilus. Microbiology 2009, 155, $1953-1965$. [CrossRef] [PubMed]

73. Arioli, S.; Monnet, C.; Guglielmetti, S.; Parini, C.; De Noni, I.; Hogenboom, J.; Halami, P.M.; Mora, D. Aspartate biosynthesis is essential for the growth of Streptococcus thermophilus in milk, and aspartate availability modulates the level of urease activity. Appl. Environ. Microbiol. 2007, 73, 5789-5796. [CrossRef] [PubMed]

74. Nicoloff, H.; Elagoz, A.; Arsene-Ploetze, F.; Kammerer, B.; Martinussen, J.; Bringel, F. Repression of the pyr operon in Lactobacillus plantarum prevents its ability to grow at low carbon dioxide levels. J. Bacteriol. 2005, 187, 2093-2104. [CrossRef] [PubMed]

75. Nicoloff, H.; Hubert, J.C.; Bringel, F. In Lactobacillus plantarum, carbamoyl phosphate is synthesized by two carbamoyl-phosphate synthetases (CPS): Carbon dioxide differentiates the Arginine-repressed from the pyrimidine-regulated cps. J. Bacteriol. 2000, 182, 3416-3422. [CrossRef] [PubMed]

76. Nicoloff, H.; Hubert, J.-C.; Bringel, F. Carbamoyl-phosphate synthetases (CPS) in lactic acid bacteria and other Gram-positive bacteria. Lait 2001, 81, 151-159. [CrossRef]

77. Bolotin, A.; Quinquis, B.; Renault, P.; Sorokin, A.; Ehrlich, S.D.; Kulakauskas, S.; Lapidus, A.; Goltsman, E.; Mazur, M.; Pusch, G.D.; et al. Complete sequence and comparative genome analysis of the dairy bacterium Streptococcus thermophilus. Nat. Biotechnol. 2004, 22, 1554-1558. [CrossRef] [PubMed]

78. Shobharani, P.; Prakash, M.; Halami, P.M. Probiotic bacillus spp. In soy-curd: Nutritional, rheological, sensory, and antioxidant properties. J. Food Sci. 2015, 80, M2247-M2256. [CrossRef] [PubMed]

79. Ma, C.; Ma, A.; Gong, G.; Liu, Z.; Wu, Z.; Guo, B.; Chen, Z. Cracking Streptococcus thermophilus to stimulate the growth of the probiotic Lactobacillus casei in co-culture. Int. J. Food Microbiol. 2015, 210, 42-46. [CrossRef] [PubMed]

80. Xie, N.; Zhou, T.; Li, B. Kefir yeasts enhance probiotic potentials of Lactobacillus paracasei h9: The positive effects of coaggregation between the two strains. Food Res. Int. 2012, 45, 394-401. [CrossRef]

81. Altieri, C.; Bevilacqua, A.; D’Amato, D.; Nobile, M.A.; Sinigaglia, M. Modelling the survival of starter lactic acid bacteria and Bifidobacterium bifidum in single and simultaneous cultures. Food Microbiol. 2008, 25, 729-734. [CrossRef] [PubMed]

82. Meng, X.C.; Stanton, C.; Fitzgerald, G.F.; Daly, C.; Ross, R.P. Anhydrobiotics: The challenges of drying probiotic cultures. Food Chem. 2008, 106, 1406-1416. [CrossRef]

83. Talwalkar, A.; Kailasapathy, K. The role of oxygen in the viability of probiotic bacteria with reference to 1 . Acidophilus and bifidobacterium spp.. Curr. Issues Intest. Microbiol. 2004, 5, 1-8. [PubMed]

84. Derzelle, S.; Hallet, B.; Ferain, T.; Delcour, J.; Hols, P. Improved adaptation to cold-shock, stationary-phase, and freezing stresses in Lactobacillus plantarum overproducing cold-shock proteins. Appl. Environ. Microbiol. 2003, 69, 4285-4290. [CrossRef] [PubMed]

85. Ventura, M.; Reniero, R.; Zink, R. Specific identification and targeted characterization of Bifidobacterium lactis from different environmental isolates by a combined multiplex-PCR approach. Appl. Environ. Microbiol. 2001, 67, 2760-2765. [CrossRef] [PubMed]

86. Talwalkar, A.; Kailasapathy, K. Metabolic and biochemical responses of probiotic bacteria to oxygen. J. Dairy Sci. 2003, 86, 2537-2546. [CrossRef]

87. Cronin, M.; Ventura, M.; Fitzgerald, G.F.; van Sinderen, D. Progress in genomics, metabolism and biotechnology of bifidobacteria. Int. J. Food Microbiol. 2011, 149, 4-18. [CrossRef] [PubMed] 
88. Long, G.; Zhu, P.; Shen, Y.; Tong, M. Influence of extracellular polymeric substances (EPS) on deposition kinetics of bacteria. Environ. Sci. Technol. 2009, 43, 2308-2314. [CrossRef] [PubMed]

89. Fu, N.; Chen, X.D. Towards a maximal cell survival in convective thermal drying processes. Food Res. Int. 2011, 44, 1127-1149. [CrossRef]

90. Santivarangkna, C.; Higl, B.; Foerst, P. Protection mechanisms of sugars during different stages of preparation process of dried lactic acid starter cultures. Food Microbiol. 2008, 25, 429-441. [CrossRef] [PubMed]

91. Looijesteijn, P.J.; Trapet, L.; de Vries, E.; Abee, T.; Hugenholtz, J. Physiological function of exopolysaccharides produced by Lactococcus lactis. Int. J. Food Microbiol. 2001, 64, 71-80. [CrossRef]

92. De Vuyst, L.; Degeest, B. Heteropolysaccharides from lactic acid bacteria. FEMS Microbiol. Rev. 1999, 23, 153-177. [CrossRef] [PubMed]

93. Degeest, B.; Janssens, B.; de Vuyst, L. Exopolysaccharide (EPS) biosynthesis by Lactobacillus sakei 0-1: Production kinetics, enzyme activities and EPS yields. J. Appl. Microbiol. 2001, 91, 470-477. [CrossRef] [PubMed]

94. Leroy, F.; de Vuyst, L. Advances in production and simplified methods for recovery and quantification of exopolysaccharides for applications in food and health. J. Dairy Sci. 2016, 99, 1-10. [CrossRef] [PubMed]

95. De Vuyst, L.; de Vin, F.; Vaningelgem, F.; Degeest, B. Recent developments in the biosynthesis and applications of heteropolysaccharides from lactic acid bacteria. Int. Dairy J. 2001, 11, 687-707. [CrossRef]

96. Welman, A.D.; Maddox, I.S.; Archer, R.H. Screening and selection of exopolysaccharide-producing strains of Lactobacillus delbrueckii subsp. Bulgaricus. J. Appl. Microbiol. 2003, 95, 1200-1206. [CrossRef] [PubMed]

97. Dal Bello, F.; Walter, J.; Hertel, C.; Hammes, W.P. In vitro study of prebiotic properties of levan-type exopolysaccharides from lactobacilli and non-digestible carbohydrates using denaturing gradient gel electrophoresis. Syst. Appl. Microbiol. 2001, 24, 232-237. [CrossRef] [PubMed]

98. Jolly, L.; Vincent, S.F.; Duboc, P.; Neeser, J.-R. Exploiting exopolysaccharides from lactic acid bacteria. Anton. Leeuwenhoek 2002, 82, 367-374. [CrossRef]

99. Harutoshi, T. Exopolysaccharides of Lactic Acid Bacteria for Food and Colon Health Applications; INTECH Open Access Publisher: Rijeka, Croatia, 2013.

100. Péant, B.; LaPointe, G.; Gilbert, C.; Atlan, D.; Ward, P.; Roy, D. Comparative analysis of the exopolysaccharide biosynthesis gene clusters from four strains of Lactobacillus rhamnosus. Microbiology 2005, 151, 1839-1851. [CrossRef] [PubMed]

101. Guillaume, E.; Berger, B.; Affolter, M.; Kussmann, M. Label-free quantitative proteomics of two bifidobacterium longum strains. J. Proteom. 2009, 72, 771-784. [CrossRef] [PubMed]

102. Leiversa, S.H.-C.C.; Robinsona, G.; Margollesb, A.; Ruas-Madiedob, P.; Lawsa, A.P. Structure of the high molecular weight exopolysaccharide produced by Bifidobacterium animalissubsp. Lactis IPLA-R1 and sequence analysis of its putative epscluster. Carbohydr. Res. 2011, 346, 2710-2717. [CrossRef] [PubMed]

103. Fanning, S.; Hall, L.J.; Cronin, M.; Zomer, A.; MacSharry, J.; Goulding, D.; O'Connell Motherway, M.; Shanahan, F.; Nally, K.; Dougan, G.; et al. Bifidobacterial surface-exopolysaccharide facilitates commensal-host interaction through immune modulation and pathogen protection. Proc. Natl. Acad. Sci. USA 2012, 109, 2108-2113. [CrossRef] [PubMed]

104. Hidalgo-Cantabrana, C.; Sanchez, B.; Milani, C.; Ventura, M.; Margolles, A.; Ruas-Madiedo, P. Exopolysaccharide biosynthesis in bifidobacterium spp.: Biological functions and a genomic overview. Appl. Environ. Microbiol. 2013. [CrossRef] [PubMed]

105. Sutherland, I. Biofilm exopolysaccharides: A strong and sticky framework. Microbiology 2001, 147, 3-9. [CrossRef] [PubMed]

106. Patel, S.; Majumder, A.; Goyal, A. Potentials of exopolysaccharides from lactic acid bacteria. Indian J. Microbiol. 2012, 52, 3-12. [CrossRef] [PubMed]

107. Ruas-Madiedo, P.; Tuinier, R.; Kanning, M.; Zoon, P. Role of exopolysaccharides produced by Lactococcus lactis subsp. Cremoris on the viscosity of fermented milks. Int. Dairy J. 2002, 12, 689-695. [CrossRef]

108. Carvalho, A.S.; Silva, J.; Ho, P.; Teixeira, P.; Malcata, F.X.; Gibbs, P. Protective effect of sorbitol and monosodium glutamate during storage of freeze-dried lactic acid bacteria. Le Lait 2003, 83, 203-210. [CrossRef]

109. Flemming, H.C.; Neu, T.R.; Wozniak, D.J. The EPS matrix: The “house of biofilm cells". J. Bacteriol. 2007, 189, 7945-7947. [CrossRef] [PubMed] 
110. Marx, J.G.; Carpenter, S.D.; Deming, J.W. Production of cryoprotectant extracellular polysaccharide substances (EPS) by the marine psychrophilic bacterium Colwellia psychrerythraea strain $34 \mathrm{~h}$ under extreme conditions. Can. J. Microbiol. 2009, 55, 63-72. [CrossRef] [PubMed]

111. Mozzi, F.; Savoy de Giori, G.; Font de Valdez, G. Udp-galactose 4-epimerase: A key enzyme in exopolysaccharide formation by Lactobacillus casei CRL 87 in controlled pH batch cultures. J. Appl. Microbiol. 2003, 94, 175-183. [CrossRef] [PubMed]

112. Öner, E.T. Microbial production of extracellular polysaccharides from biomass. In Pretreatment Techniques for Biofuels and Biorefineries; Fang, Z., Ed.; Springer Berlin Heidelberg: Berlin, Germany, 2013; pp. 35-56.

113. Osman, A.; Tzortzis, G.; Rastall, R.A.; Charalampopoulos, D. Bbgiv is an important bifidobacterium $\beta$-galactosidase for the synthesis of prebiotic galactooligosaccharides at high temperatures. J. Agric. Food Chem. 2011, 60, 740-748. [CrossRef] [PubMed]

114. Tymczyszyn, E.E.; Sosa, N.; Gerbino, E.; Hugo, A.; Gómez-Zavaglia, A.; Schebor, C. Effect of physical properties on the stability of lactobacillus bulgaricus in a freeze-dried galacto-oligosaccharides matrix. Int. J. Food Microbiol. 2012, 155, 217-221. [CrossRef] [PubMed]

115. Santos, E.G.; Costa, F.G.P.; Silva, J.H.V.; Martins, T.D.D.; Figueiredo-Lima, D.F.; Macari, M.; Oliveira, C.J.B.; Givisiez, P.E.N. Protective effect of mannan oligosaccharides against early colonization by salmonella enteritidis in chicks is improved by higher dietary threonine levels. J. Appl. Microbiol. 2013, 114, 1158-1165. [CrossRef] [PubMed]

116. Nandal, K.; Sehrawat, A.R.; Yadav, A.S.; Vashishat, R.K.; Boora, K.S. High temperature-induced changes in exopolysaccharides, lipopolysaccharides and protein profile of heat-resistant mutants of Rhizobium sp. (Cajanus). Microbiol. Res. 2005, 160, 367-373. [CrossRef] [PubMed]

117. Hongpattarakere, T.; Cherntong, N.; Wichienchot, S.; Kolida, S.; Rastall, R.A. In vitro prebiotic evaluation of exopolysaccharides produced by marine isolated lactic acid bacteria. Carbohydr. Polym. 2012, 87, 846-852. [CrossRef]

118. Ruijssenaars, H.J.; Stingele, F.; Hartmans, S. Biodegradability of food-associated extracellular polysaccharides. Curr. Microbiol. 2000, 40, 194-199. [CrossRef] [PubMed]

119. Mårtensson, O.; Biörklund, M.; Lambo, A.M.; Dueñas-Chasco, M.; Irastorza, A.; Holst, O.; Norin, E.; Welling, G.; Öste, R.; Önning, G. Fermented, ropy, OAT-based products reduce cholesterol levels and stimulate the bifidobacteria flora in humans. Nutr. Res. 2005, 25, 429-442. [CrossRef]

120. Leroy, F.; de Vuyst, L. Lactic acid bacteria as functional starter cultures for the food fermentation industry. Trends Food Sci. Technol. 2004, 15, 67-78. [CrossRef]

121. Guergoletto, K.B.; Magnani, M.; Martin, J.S.; Andrade, C.G.T.d.J.; Garcia, S. Survival of Lactobacillus casei (LC-1) adhered to prebiotic vegetal fibers. Innov. Food Sci. Emerg. Technol. 2010, 11, 415-421. [CrossRef]

122. Santivarangkna, C.; Kulozik, U.; Foerst, P. Inactivation mechanisms of lactic acid starter cultures preserved by drying processes. J. Appl. Microbiol. 2008, 105, 1-13. [CrossRef] [PubMed]

123. Gourbeyre, P.; Denery, S.; Bodinier, M. Probiotics, prebiotics, and synbiotics: Impact on the gut immune system and allergic reactions. J. Leukoc. Biol. 2011, 89, 685-695. [CrossRef] [PubMed]

124. Schrezenmeir, J.; de Vrese, M. Probiotics, prebiotics, and synbiotics-Approaching a definition. Am. J. Clin. Nutr. 2001, 73, 361s-364s. [PubMed]

125. Wollowski, I.; Rechkemmer, G.; Pool-Zobel, B.L. Protective role of probiotics and prebiotics in colon cancer. Am. J. Clin. Nutr. 2001, 73, 451s-455s. [PubMed]

126. Gomi, A.; Harima-Mizusawa, N.; Shibahara-Sone, H.; Kano, M.; Miyazaki, K.; Ishikawa, F. Effect of Bifidobacterium bifidum BF-1 on gastric protection and mucin production in an acute gastric injury rat model. J. Dairy Sci. 2012, 96, 832-837. [CrossRef] [PubMed]

127. Fanning, S.; Hall, L.J.; van Sinderen, D. Bifidobacterium breve UCC2003 surface exopolysaccharide production is a beneficial trait mediating commensal-host interaction through immune modulation and pathogen protection. Gut Microb. 2012, 3, 420-425. [CrossRef] [PubMed]

128. Conover, M.S.; Sloan, G.P.; Love, C.F.; Sukumar, N.; Deora, R. The bps polysaccharide of bordetella pertussis promotes colonization and biofilm formation in the nose by functioning as an adhesin. Mol. Microbiol. 2010, 77, 1439-1455. [CrossRef] [PubMed]

(C) 2016 by the authors; licensee MDPI, Basel, Switzerland. This article is an open access article distributed under the terms and conditions of the Creative Commons Attribution (CC-BY) license (http://creativecommons.org/licenses/by/4.0/). 